\title{
PENGARUH KECERDASAN EMOSIONAL DAN MINAT BELAJAR TERHADAP PRESTASI BELAJAR MATEMATIKA DI SMAN JAKARTA SELATAN
}

\author{
INDAH MAYANG PURNAMA \\ indahmayang016@gmail.com \\ Program Studi Pendidikan Matematika Fakultas Teknik, Matematika dan IPA \\ Universitas Indraprasta PGRI
}

\begin{abstract}
Abstrak.Tujuan penelitian ini untuk mengetahui pengaruh kecerdasan emosional dan minat belajar terhadap prestasi belajar matematika.Metode penelitian yang digunakan yaitu survei dengan pendekatan korelasional. Sampel berukuran 98 siswa yang dipilih secara random dari seluruh siswa SMAN di Kota Madya Jakarta Selatan. Analisis data dengan metode statistik deskriptif dan analisis jalur. Hasil penelitian menunjukkan bahwa: (1) terdapat pengaruh langsung yang signifikan Kecerdasan Emosional terhadap Prestasi Belajar Matematika. (2) Terdapat pengaruh langsung yang signifikan Minat Belajar Matematika terhadap Prestasi Belajar Matematika. (3) Terdapat pengaruh langsung yang signifikan Kecerdasan Emosional terhadap Minat Belajar Matematika. (4) Terdapat Pengaruh tidak langsung yang signifikan Kecerdasan Emosional terhadap Prestasi Belajar Matematika melalui Minat Belajar Matematika. Upaya meningkatkan prestasi belajar matematika siswa dapat dilakukan dengan meningkatkan kecerdasan emosional siswa dan minat belajar matematika siswa. Kecerdasan emosional siswa dapat ditingkatkan melalui kesadaran diri terhadap lingkungan sosialnya sehingga kecerdasan emosional siswa meningkat dan minat belajar matematika siswa ikut meningkat. Selain kecerdasan emosional yang tinggi yang dapat meningkatkan minat belajar matematika siswa metode yang guru gunakan dalam mengajar juga dapat meningkatkan minat belajar matematika.
\end{abstract}

Kata Kunci: Kecerdasan Emosional, Minat Belajar, Prestasi Belajar Matematika.

\section{PENDAHULUAN}

Ki Hajar Dewantara mendefenisikan pendidikan sebagai tuntutan di dalam hidup tumbuhnya anak-anak, maksudnya pendidikan bertujuan dalam pendidikan bertujuan dalam menuntun (bukan menentukan) segala ketentuan kodrat (kehendak tuhan) yang ada pada anak-anak tersebut, agar kelak ketika mereka sebagai manusia dan sebagai anggota masyarakat dapat meraih keselamatan dan kebahagiaan setinggitingginya. Sedangkan menurut plato pendidikan adalah proses yang dilakukan seumur hidup yang dimulai dari ia lahir hingga kematiannya, yang membuat seseorang bersemangat dalam mewujudkan warga negara yang ideal dan mengajarkannya bagaimana cara memimpin dan mematuhi yang benar. Plato pun menambahkan pendidikan tidak hanya menyediakan ilmu pengetahuan dan kemampuan akan tetapi nilai, pelatihan insting, membina tingkah laku dan sikap yang benar.Pernyataan plato sejalan dengan dengan UU No. 20 tahun 2003, pendidikan nasional adalah pendidikan yang berdasarkan pancasila dan Undang undang Dasar Republik Indonesia tahun 1945 yang berakar pada nilai-nilai agama, kebudayaan nasional Indonesia dan tanggap terhadap tuntutan perubahan zaman.

Tujuan dari pendidikan nasional Indonesia adalah mengembangkan kemampuan dan membentuk watak serta peradaban bangsa yang bermartabat dalam rangka mencerdaskan kehidupan bangsa, bertujuan untuk berkembangnya potensi peserta didik agar menjadi manusia yang beriman dan bertakwa kepada Tuhan Yang Maha Esa, 
berakhlak mulia, sehat, berilmu, cakap, kreatif, mandiri, dan menjadi warga negara yang demokratis serta bertanggung jawab. Begitupun menurut Socrates tujuan pendidikan yang benar menurutnya adalah untuk merangsang penalaran yang cermat dan disiplin mental yang akan menghasilkan perkembangan intelektual yang terus menerus dan standar moral yang tinggi. Namun kenyataanya pendidikan di Indonesia masih banyak yang harus kita sempurnakan. Proses menuju tujuan pendidikan yang mulia itu sendiri tidak berjalan berimbang. Dimana realitanya dilapangan pendidikan Idonesia hanya menitik beratkan pendidikan hanya pada aspek kognitif saja yaitu IQ (intelegent Quotion) dengan diadakannya Ujian Nasioanl ini membuktikan bahwa pendidikan di Indonesia ini belum mencapai kepada tujuan nasional kita yang tidak hanya menekankan aspek kognitif saja melainkan aspek afektif dan psikomotor juga.

Dalam proses kegiatan belajar mengajar di sekolah, banyak orang yang berpendapat bahwa untuk meraih prestasi yang tinggi dalam belajar, seseorang harus memiliki Intelligence Quotient (IQ) yang tinggi, karena intelegensi merupakan bekal potensi yang akan memudahkan dalam belajar sehingga dapat menghasilkan prestasi belajar yang optimal. Menurut Solso (2008: 456) intelegensi manusia adalah kemampuan untuk memperoleh, memanggil kembali (recall), dan menggunakan pengetahuan untuk memahami konsep-konsep abstrak maupun konkret dan hubungan antara objek dan ide, serta menerapkan pengetahuan secara tepat.

Namun di dalam kegiatan belajar mengajar yang kita temui sering kita dapatkan siswa yang tidak dapat meraih prestasi belajar yang setara dengan kemampuan intelegensinya. Ada beberapa siswa dengan keMampuan intelegensi yang relative tinggi tetapi ia memperoleh prestasibelajar yang relative rendah, namun ada juga siswa yang memiliki kemampuan intelegensi relative rendah, dapat meraih prestasi belajar yang relative tinggi. Maka jelas bahwa taraf intelegensi bukan satu-satunya faktor yang menentukan keberhasilan seseorang, karena ada faktor lain yang mempengaruhinya. Menurut Goleman (2000: 44), kecerdasan Intelektual (IQ) hanya menyumbang 20\% bagi kesuksesan seseorang, sedangkan $80 \%$ adalah sumbangan dari faktor lain, diantaranya kecerdasan emosional (EQ) yaitu kemampuan memotivasi diri sendiri, mengatasi frustasi, mengontrol desakan hati, mengatur suasana hati, berempati serta kemampuan bekerjasama.

Kedua kecerdasan ini sangat diperlukan di dalam proses kegiatan belajar mengajar, IQ tidak dapat bekerja maksimal tanpa ada partisipasi dari kecerdasan emosional terhadap mata pelajaran yang disampaikan disekolah. Maka jelas bahwa antara IQ dan EQ mereka adalah kecerdasan yang ada pada manusia yang saling bersinergi. Keseimbangan IQ dan EQ merupakan kunci keberhasilan belajar siswa di sekolah (Goleman, 2002).

Gardner dalam bukunya yang berjudul Frame Of Mind (Goleman, 2000: 50-53) mengatakan bahwa bukan hanya satu jenis kcerdasan yang monolitik yang penting untuk meraih sukses dalam kehidupan, melainkan ada spektrum kecerdasan yang lebar dengan tujuh varietas utama yaitu linguistik, matematika/logika, spasial, kinestetik, musik, interpersonal dan intrapersonal.kecerdasan ini dinamakan oleh gardner sebagai kecerdasan pribadi yang disebut oleh Daniel Goleman sebagai kecerdasan emosional.

Selain kecerdasan emosional, minat belajar matemtika siswa juga menjadi faktor yang mempengaruhi prestasi belajar siswa. Minat sangatlah berpengaruh dengan prestasi yang akan didapatkan siswa. Dengan minat belajar yang tinggi maka proses kegiatan belajar mengajar akan semakin menyenangkan sehingga siswa tidak merasa terbebani. Siswa yang memiliki minat terhadapkegiatan belajar mengajar akan berusaha lebih keras dibandingkan siswa yang memiliki minat yang kurang. Minat yang tinggi yang dimiliki siswa terhadap suatu mata pelajaran, memungkinkan siswa memberikan 
perhatian yang tinggi terhadap mata pelajaran itu sehingga memungkinkan pula memiliki prestasi yang tinggi. Oleh karena itu untuk mencapai prestasi yang tinggi, selain kecerdasan, minat siswa juga diperlukan, sebab tanpa minat proses belajar mengajar berjalan kurang efektif.

Matematika merupakan mata pelajaran yang diberikan kepada siswa dalam porsi yang cukup banyak sesuai dengan kurikulum yang diberikan oleh DIKNAS. Akan tetapi mayoritas siswa kurang menyukai mata pelajaran matematika, matematika adalah momok yang menyeramkan bagi mereka. Hal ini dipengaruhi oleh beberapa faktor yang terbagi menjadi dua yang pertama faktor internal: kecerdasan emosional dan minat siswa itu sendiri, dan yang kedua faktor eksternal yang datangnya dari guru kurangnya kemampuan guru menciptakan situasi yang membuat siswa tertarik pada matematika juga sangat mempengaruhi. Kurang jelasnya nilai kegunaan matematika yang tidak dijabarkan oleh gurupun adalah salah satu faktor yang membuat siswa kurang berminat dalam mengikuti kegiatan belajar mengajar pada mata pelajaran matematika, banyak siswa yang menilai matematika tidaklah ada kaitannya dengan kehidupan sehari-hari sehingga siswa kurang antusias terhadap persoalan yang ada, guru seharusnya memberikan materi matematika secara aplikatif sehingga siswa mampu mencoba memecahkan permasalahannya. Belajar matematika akan lebih bermakna jika siswa "mengalaminya" dengan apa yang dipelajarinya, bukan "mengetahuinya".

Terlihat setelah apa yang dijabarkan diatas maka jika kecerdasan emosional dimiliki oleh siswa maka sebagian besar permasalahan belajar yang mempengaruhi prestasi belajar siswa dapat diselesaikan. Selama ini kita hanya berfokus kepada kemampuan Intelegence Quotin (IQ) atau ranah kognitif saja tanpa memikirkan kecerdasan emosional yang dimiliki siswa. Tidak dapat kita pungkiri bahwa Intelegence Quotin (IQ) dan Emotional Quiton (EQ) merupakan faktor yang mempengaruhi prestasi belajar siswa.

Namun dalam perjalanannya bukan hanya rendahnya IQ dan EQ yang dimiliki siswa yang mempengaruhi kegiatan belajar mengajar. Minat juga berpengaruh besar di dalam kegiatan belajar mengajar yang di alami siswa. Kurang jelasnya nilai manfaat pelajaran matematika yang diberikan guru mempengaruhi kurangnya minat siswa terhadap mata pelajaran matematika sehingga mempengaruhi prestasi yang didapatkan siswa.

Berdasarkan uraian-uraian di atas, peneliti tertarik untuk melakukan penelitian dengan judul " Pengaruh Kecerdasan Emosional dan Minat Belajar Matematika Siswa Terhadap Prestasi Belajar Matematika Siswa”.

\section{TINJAUAN PUSTAKA}

\section{Prestasi Belajar Matematika}

Prestasi belajar matematika yang dimiliki siswa selama proses kegiatan belajar mengajar adalah sebuah hasil dari evaluasi yang guru berikan kepada siswa sehingga memperlihatkan sejauh mana pemahaman siswa terhadap apa yang guru berikan selama proses kegiatan belajar mengajar berlangsung. Dimana hasil dari evaluasi itu sendiri merupakan prestasi yang berupa nilai-nilai atau angka-angka sebagai tingkat pencapaian siswa di dalam belajar matematika. Pada dasarnya pengajaran yang ditanamkan matematika adalah bagaimana siswa berpikir logis, sistematis, intergratif dan kreatif. Sehingga akan menghasilkan daya mental anak didik yang kuat. Proses pembelajaran matematika yang memiliki dasar-dasar diatas sangatlah jelas bahwa belajar matematika haruslah saling berkesinambungan atau continue

Prestasi belajar merupakan faktor yang sangat penting bagi siswa didik maupun bagi pendidik. Prestasi belajar yang baik merupakan cita-cita setiap siswa maupun 
pendidik.Karena prestasi belajar siswa merupakan sebuah tolak ukur keberhasilan proses belajar mengajar yang dilakukan oleh siswa dan pendidik. Apabila prestasi yang didapatkan siswa baik, maka dapat dikatakan proses belajar mengajar berhasil baik, akan tetapi jika prestasi belajar yang dicapai siswa rendah, maka dapat dikatakan behwa proses belajar mengajar yang dilakukan oleh guru belum berhasil dengan baik.

Usaha untuk mengetahui Prestasi Belajar siswa dilakukan melalui evaluasi. Evaluasi dimaksudkan untuk melihat sampai sejauh mana langkah bantuan yang telah diberikan untuk mencapai hasil yang diharapkan. Dengan evaluasi dapat ditentukan tingkat keberhasilan suatu program, sekaligus juga dapat diukur hasil-hasil yang dicapai oleh suatu program.

Pelajaran matematika pada dasarnya sangatlah sering kita dapatkan dikehidupan sehari-hari, namun dalam hal ini masih banyak guru matematika yang tidak menyampaikan nilai manfaat dari belajar matematika itu sendiri. Kurangnya informasi yang disampaikan oleh guru tentang nilai manfaat dari belajar matematika menyebabkan proses kegiatan belajar mengajar di dalam kelas menjadi membosankan. Hal ini yang menyebabkan kurangnya tingkat Prestasi Belajar Siswa.

Berdasarkan uraian yang dikemukakan diatas, maka prestasi belajar matematika adalah kemampuan yang dimiliki siswa setelah mengikuti proses kegiatan belajar mengajar yang dibatasi pada ranah kognitif dalam tingkatan ingatan, pemahaman dan aplikasi, yang ditunjukkan dengan nilai yang diberikan oleh guru. Prestasi belajar matematika yang siswa miliki merupakan hasil yang di dapatkan siswa selama proses kegiatan belajar mengajar berlangsung melalui evaluasi yang diberikan oleh guru. Evaluasi yang diberikan oleh guru merupakan rangkaian tes pada ranah kognitif siswa yang dapat mengukur sejauh mana pemahaman siswa di dalam kegiatan belajar mengajar.

\section{Kecerdasan Emosional}

Istilah 'kecerdasan emosional' pertama kali dilontarkan pada tahun 1990 oleh dua orang psikolog bernama Peter Salovey dari Harvard University dan John Mayer dari University of New Hampshire (Shapiro, 1997) untuk menerangkan kualitas-kualitas emosional yang tampaknya penting bagi keberhasilan seseorang. Salovey dan Mayer mendefinisikan kecerdasan emosional (EQ) sebagai berikut " Himpunan bagian dari kecerdasan social yang melibatkan kemampuan memantau perasaan social yang melibatkan kemampuan pada orang lain, memilah-milah semuanya dengan menggunakan informasi itu untuk membimbing pikiran dan tindakan," (Shapiro, 1997:8).

Menurut Howard Gardner dalam Cepi dan Risma (2008:19) kecerdasan emosi terdiri atas banyak kecakapan, diantaranya intrapersonal intelligence dan interpersonal intelligence. Intrapersonal intelligence merupakan kecakapan mengenali perasaan diri sendiri yang terdiri atas: 1)Kesadaran diri, meliputi keadaan emosi, penilaian pribadi, dan percaya diri. 2)Pengaturan diri, meliputi pengendalian diri, dapat dipercaya, waspada, adptif dan inovatif. 3)Motivasi, meliputi dorongan berprestasi, komitmen, inisiatif, dan optimis.Adapun interpersonal intelligence merupakan kecakapan yang berhubungan dengan orang lain yang terdiri atas: 1) Empati, meliputi memahami orang lain, pelayanan, mengembangkan orang lain, mengatasi keragaman, dan kesadaran politis. 2) Keterampilan social, meliputi pengaruh, komunikasi, kepemimpinan, katalisator perubahan, manajemen konflik, pengikat jaringan, kolaborasi, dan koperasi serta kerja tim.

Menurut Goleman (2002:512), kecerdasan emosional adalah kemampuan seseorang mengatur kehidupan emosinya dengan intelegensi ( to manage our emosional life with intelligence); menjaga keselarasan emosi dan pengungkapannya (the appropriateness of emotion and its expression) melalui keterampilan kesadaran diri, 
pengendalian diri, motivasi diri, empati, dan keterampilan social. Goleman berpendapat bahwa kecerdasan emosional adalah kemampuan lebih yang dimiliki seseorang dalam memotivasi diri, ketahanan dalam menghadapi kegagalan, mengendalikan emosi dan menunda kepuasan, serta mengatur keadaan jiwa. Goleman memaparkan beberapa hasil penelitiannya dalam bukunya yang berjudul Emotional Intelligence. Koordinasi suasana hati adalah inti dari hubungan social yang baik. Apabila seorang pandai menyesuaiakan diri dengan suasana hati individu yang lain, orang itu akan memiliki tingkat emosional yang baik dan akan lebih mudah menyesuaikan diri dalam pergaulan sosial serta lingkungannya. Pendapat ini didukung oleh Cooper dan Sawaf( 1998:34) "every feeling is a signal. It is signifies that something you value is being called into question on there is an opportunity to be seized-to strengthen a relationship, for example, or to make change and create something new. Every emotion is wake-up call to capture your attention. By design, it's supposed to move you- to ask a question or a stand."Peduli terhadap perasaan, artinya peduli terhadap perubahan dan perbaikan. Jika perasaan diabaikan, perubahan tidak terjamah atau tidak ada perubahan yang akan dilakukan dengan tepat dan benar. Perasaan harus dikendalikan dengan menghayati dorongan (impulse) yang terasa, mengarahkannya, mengalihkan perhatian pada hal yang produktif dan konstruktif. Jadi emosi akan memberi umpan balik jika dikelola atau dikendalikan dengan baik.

Keterampilan EQ bukanlah lawan dari IQ atau keterampilan kognitif, melainkan keduanya berinteraksi secara dinamis baik secara konseptual maupun di dunia nyata. Jadi Kecerdasan emosional atau yang biasa dikenal EQ (Emotional quotient) adalah kemampuan seseorang untuk menerima, menilai, mengelola, serta mengontrol emosi dirinya dan orang lain disekitarnya. Dalam hal ini emosi mengacu kepada perasaan terhadap informasi akan suatu hubungan, sedangkan kecerdasan intelijen mengacu pada kapasitas untuk memberikan alasan yang valid akan suatu hubungan. Kecerdasan emosional (EQ) belakangan ini dinilai tidak kalah penting dengan kecerdasan intelektual (IQ).

Berdasarkan pendapat para ahli diatas terlihat bahwa kecerdasan emosional berpengaruh terhadap kecerdasan intelektual yang bemuara pada keberhasilan seseorang, khususnya pada orang-orang yang memiliki kecerdasan akademis tinggi tetapi memiliki tingkat kecerdasan yang rendah, mereka cendrung memiliki rasa gelisah yang tidak beralasan, terlalu kritis, rewel, cendrung menarik diri, terkesan dingin dan cendrung sulit mengekspresikan kekesalan dan kemarahannya secara tepat, orang-orang seperti ini sering menjadi sumber masalah. Karena sifat-sifat diatas, bila seseorang memiliki IQ tinggi namun taraf kecerdasan emosionalnya rendah maka cendrung akan terlihat kepala, sulit bergaul, mudah frustasi, tidak mudah percaya kepada orang lain, tidak peka dengan kondisi lingkungan dan cendrung putus asa bila mengalami stress. Kondisi sebaliknya, dialami oleh orang-orang yang memiliki taraf IQ rata-rata namun memiliki kecerdasan emosional yang tinggi mereka umumnya mampu menguasai dan mengontrol serta memotivasi diri dengan baik dan lebih bijak memahami orang lain, serta bisa bekerjasama dengan baik.

Jadi dapat disimpulkan bahwa kecerdasan emosional adalah kemampuan seseorang dalam mengendalikan emosinya secara cerdas berdasarkan indicator-indikator kecerdasan emosional seperti: mengenali emosi diri, mengelola dan mengontrol emosi, memotivasi diri, mengenali emosi orang lain (empati), kemampuan untuk membina hubungan ( kerjasama) dengan orang lain, serta memahami dan mengontrol emosi diri sendiri dan orang lain secara akurat, sehingga dapat menggunakan emosi dengan baik dan mengelolanya menjadi sebuah kecerdasan yang berguna untuk hal-hal yang positif. 


\section{Minat Belajar}

Belajar adalah suatu proses perubahan tingkah laku individu melalui interaksi dengan lingkungannya. Belajar bersifat aktif, siswa sebagai peserta didik tidak akan mampu merubah prilaku jika ia tidak aktif mengikuti setiap proses yang berlangsung. Anni, dkk (2004:86) menyatakan rasa percaya diri dalam diri siswa dapat mendorong tumbuhnya minat belajar. Orang tua maupun guru perlu meningkatkan rasa percaya diri pada anak, karena dengan adanya rasa percaya diri akan menumbuhkan minat anak.

Minat belajar adalah keinginan siswa untuk mewujudkan harapan guru, orang tua dan teman bahwa dirinya termasuk siswa yang memiliki kemampuan dan kecakapan dalam belajar. Dengan tercapainya keinginan tersebut maka akan tumbuh minat belajar.Minat belajar merupakan dorongan batin yang tumbuh dari seorang siswa untuk meningkatkan kebiasaan belajar. Minat belajar akan tumbuh saat siswa memiliki keinginan untuk meraih nilai terbaik, atau ingin memenangkan persaingan dalam belajar dengan siswa lainnya. Minat belajar juga dapat dibangun dengan menetapkan cita-cita yang tinggi sesuai dengan bakat dan kemampuan siswa.

Morse dan Wingo dalam Sahabuddin (2003:126) mengatakan bahwa seorang anak atau siswa adalah kunci untuk proses belajarnya. Menangkap minatnya dan ia akan berusaha dengan kekuatan imajinasi dan belajar dengan ketepatan yang luar biasa dan rinci. Minat siswa berhubungan erat dengan kebiasaan dalam memperoleh pengalamanpengalaman yang memuaskan dan ketika menetapkan tujuan cendrung secara terus menerus menitik beratkan pada tujuan-tujuan dan maksud tertentu. Selain orang tua dan siswa itu sendiri guru juga merupakan orang yang mengetahui kecendrungan minat pada siswanya. Disinilah guru dituntut untuk menumbuhkan minat-minat yang ada dan berusaha untuk meningkatkan minat siswa tersebut kearah kemajuan yang lebih tinggi. Surya (2007:46) menyampaikan beberapa langkah untuk meningkatkan minat belajar diantaranya dengan menggugah tentang kebutuhan akan belajar. Strategi dalam menggugah kebutuhan akan belajar dapat dilakukan dengan membangun dialog dan pendekatan personal, mengembangkan komunikasi kondusif dengan anak. Dalam hal ini orang tua atau guru sebaiknya tidak hadir dengan mengintervensi atau mendikte tetapi memberi dukungan dan motivasi untuk berada pada jalur yang tepat sebagai seorang pelajar.

Membangun minat belajar siswa tidak dapat dilepaskan seluruhnya pada siswa, unsur orang tua dan guru sangat berperan dalam membangun prilaku belajar siswa. Peran guru dan orang tua adalah memberi dukungan moril pada siswa bahwa mereka memiliki kemampuan dan bakat untuk yang cukup baik sehingga tidak ada hal yang perlu dirisaukan dan meyakinkan siswa bahwa pada dasarnya mereka memiliki kemampuan untuk menguasai materi matematika sesulit apa pun. Hardwinoto dan Setiabudhi (2006:111) menginformasikan bahwa minat siswa terhadap matematika akan bertambah apabila ia dapat memahami dan menyelesaikan soal matematika dengan mudah. Seorang siswa yang mampu memperoleh nilai terbaik dalam ulangan matematika secara tidak langsung akan memberi rasa bangga, yang dengan rasa bangga tersebut terbentuk minat untuk mencapai nilai yang lebih baik, selanjutnya keinginan tersebut akan memacu lahirnya minat belajar.

Dari uraian diatas dapat disimpulkan bahwa minat belajar merupakan dorongan batin yang tumbuh dari seorang siswa untuk meningkatkan kebiasaan belajar. Sedangkan minat belajar matematika siswa adalah ketertarikan siswa pada materi pelajaran matematika yang ditandai dengan adanya dorongan yang tinggi untuk belajar, mengerahkan perhatian serta pikirannyaa untuk memperoleh pengetahuan dan mencapai pemahaman tentang materi pelajaran matematika seperti: 1) Perasaan senang siswa dalam memberikan perhatian terhadap mata pelajaran matematika. 2) Ketekunan dalam 
mempelajari mata pelajaran matematika. 3) Kecendrungan untuk berusaha aktif meraih manfaat yang diharapkan. 4) Memiliki keterampilan atau kemampuan dalam mata pelajaran matematika.

\section{METODE}

Penelitian ini merupakan penelitian kuantitatif dengan menggunakan metode survey pada SMA Negeri di Kota Madya Jakarta Selatan. Penelitian survey ini adalah metode penelitian dengan menggunakan data masa lalu atau sekarang tanpa memberikan perlakuan terlebih dahulu oleh peneliti. Pada penelitian ini desain penelitian yang digunakan adalah analisis jalur yaitu desain penelitian yang dilakukan jika antara variabel $\mathrm{X}_{1}$ dan $\mathrm{X}_{2}$ terdapat hubungan atau dengan kata lain terdapat variable intervening yaitu $\mathrm{X}_{2}$ pada penelitian tersebut (Supardi, 2013).Desain penelitian ini digunakan untuk mengetahui ada tidaknya pengaruh antara ketiga variable tersebut baik secara langsung maupun tidak langsung. Konstelasi masalah pada penelitian ini adalah sebagai berikut:

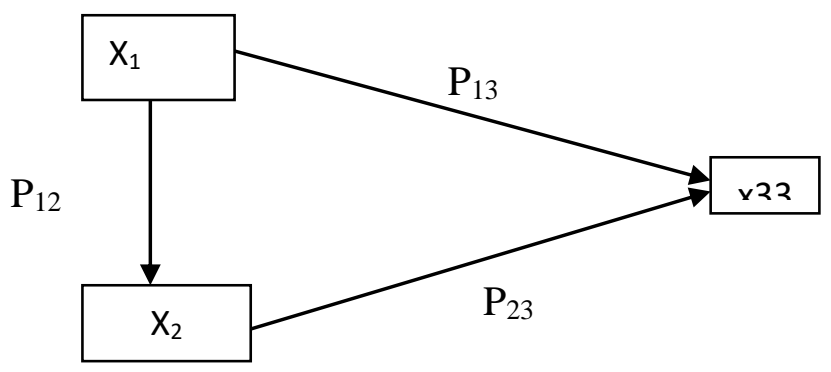

Gambar 1. konstelasi masalah penelitian

Keterangan:

$\mathrm{X}_{1}$ : Kecerdasan Emosional

$\mathrm{X}_{2}$ : Minat Belajar Matematika

X3: penguasaan Konsep Matematika

\section{HASIL DAN PEMBAHASAN}

\section{Hasil Penelitian}

Skor kecerdasan emosional siswa yang diperoleh dari para responden mempunyai rata-rata 130,48 dengan simpangan baku 11,881, median 130,00, skor minimum 104 dan skor maksimum 170. Banyaknya butir pertanyaan dalam instrumen kecerdasan emosional adalah 34 butir dengan skor maksimum tiap butir pertanyaan adalah 5, maka skor rata-rata tiap pertanyaan adalah 3,8376 atau 76,75\% dari rata-rata, hal ini menunjukkan bahwa rata-rata skor kecerdasan emosional siswa termasuk sedang. Skor simpangan baku 11,88 atau sama dengan 9,1\% dari rata-rata, menunjukkan perbedaan jawaban antar responden termasuk rendah. Hal ini menunjukkan bahwa tingkat kecerdasan emosional responden tidak banyak beragam.

Skor minat belajar matematika siswa yang diperoleh dari para responden mempunyai rata-rata 117,72 dengan simpangan baku11,581, median 1117,00, skor minimum 87 dan skor maksimum 153. Banyaknya butir pertanyaan dalam instrumen minat belajar matematika adalah 35 butir dengan skor maksimum tiap butir pertanyaan adalah 5, maka skor rata-rata tiap pertanyaan adalah 3,3634 atau 67,26\% dari rata-rata, hal ini menunjukkan bahwa rata-rata skor minat belajar matematika siswa termasuk sedang. Skor simpangan baku 11,58 atau sama dengan 9,83\% dari rata-rata, menunjukkan perbedaan jawaban antar responden termasuk rendah. Hal ini menunjukkan bahwa minat belajar matematika responden tidak banyak beragam. 
Skor prestasi belajar matematika siswa yang diperoleh dari para responden mempunyai rata-rata 24,99 dengan simpangan baku 3,795, median 25,00, skor minimum 18 dan skor maksimum 37. Hal ini menunjukkan bahwa rata-rata prestasi belajar matematika siswa cukup tinggi. Skor simpangan baku 3,795 atau sama dengan 15,18\% dari rata-rata, menunjukkan perbedaan jawaban antar responden termasuk rendah. Hal ini menunjukkan bahwa prestasi belajar matematika responden tidak banyak beragam.

Untuk melukis dan menguji hubungan antar variabel penelitian, peneliti dalam penelitian ini menggunakan Analisis Jalur (Path Analysis).

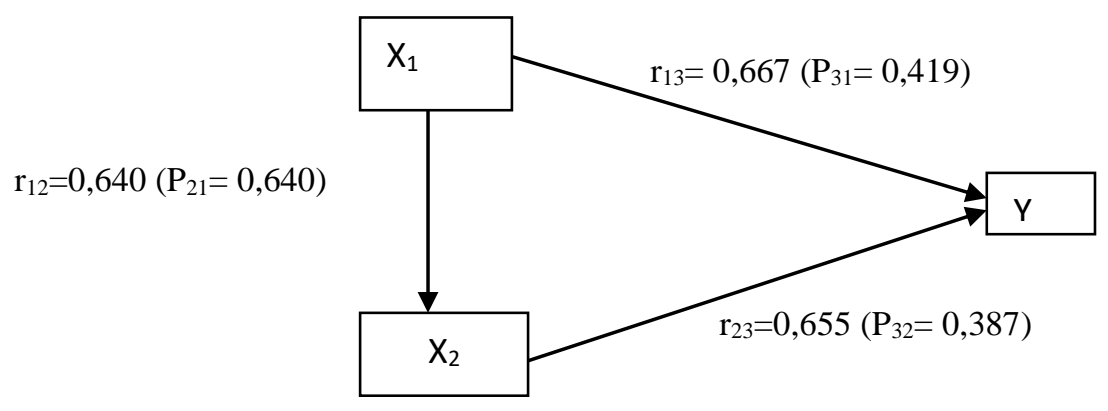

Gambar 2. Diagram Koefisien Korelasi dan Koefisien Jalur

Keterangan: Angka di luar kurung adalah Koefisien Korelasi dan angka di dalam kurung adalah Koefisien Jalur.

Berdasarkan perhitungan menurut koefisien korelasi yang diperoleh dari koefisien jalur, koefisien jalur menunjukkan kuatnya pengaruh variable independen terhadap variable dependen. Jika koefisien jalur rendah dibawah 0,05 maka jalur tersebut dianggap tidak signifikan dan dapat dihilangkan (Sujana, 2008:302).

Dari koefisien jalur diperoleh angka yang signifikan > 0,05. Hal ini membuktikan bahwa diagram jalur yang disusun dapat diterima, hal ini membuktikan bahwa:

1) Terdapat pengaruh langsung $X_{1}$ terhadap $Y$, dan juga pengaruh tidak langsung $X_{1}$ terhadap Y melalui $\mathrm{X}_{2}$.

2) Terdapat pengaruh langsung $X_{1}$ terhadap $X_{2}$

3) Terdapat pengaruh langsung $X_{2}$ terhadap $Y$

1. Pengujian Hipotesis kesatu

Untuk $\alpha=0,05$ dan $\mathrm{dk}=\mathrm{n}-\mathrm{k}-1=98-1-1=96$ pada uji dua pihak diperoleh nilai $\mathrm{t}_{\text {Table }}=\mathrm{t}_{\mathrm{t}}$ $=1,980$. Karena nilai $t_{h}>t_{t}(4,594>1,980)$ maka $H_{1}$ diterima dan dapat disimpulkan terdapat pengaruh langsung Kecerdasan Emosional terhadap Prestasi Belajar Matematika Siswa.

\section{Pengujian Hipotesis kedua}

Untuk $\alpha=0,05$ dan $\mathrm{dk}=\mathrm{n}-\mathrm{k}-1=98-2-1=95$ pada uji dua pihak diperoleh nilai $\mathrm{t}$ table $=$ $\mathrm{tt}=1,980$. Karena nilai $\mathrm{t}_{\mathrm{h}}>\mathrm{t}_{\mathrm{t}}(4,236>1,980)$ maka $\mathrm{H}_{1}$ diterima dan dapat disimpulkan terdapat pengaruh langsung Minat belajar Matematika Siswa terhadap Prestasi Belajar Matematika.

3. Pengujian Hipotesis ketiga

Untuk $\alpha=0,05$ dan $\mathrm{dk}=\mathrm{n}-\mathrm{k}-1=98-1-1=96$ pada uji dua pihak diperoleh nilai $\mathrm{t}_{\text {table }}=\mathrm{t}_{\mathrm{t}}$ $=1,980$. Karena nilai $t_{h}>t_{t}(8,156>1,980)$ maka $H_{1}$ diterima dan dapat disimpulkan terdapat pengaruh langsung Kecerdasan Emosional terhadap Minat belajar Matematika Siswa. 


\section{Pengujian Hipotesis keempat}

Untuk $\alpha=0,05$, dan $\mathrm{dk}=\mathrm{n}-\mathrm{k}-1=95$ pada uji dua pihak diperoleh nilai t table $=1,980$. Karena nilai $t_{h}>t_{t}(2,97>1,980)$ maka $H 1$ diterima dan dapat disimpulkan terdapatpengaruh tidak langsung yang signifikan Kecerdasan Emosional terhadap Prestasi Belajar Matematika melalui Minat Belajar Matematika Siswa.

\section{Pembahasan}

\section{Pengaruh Langsung Kecerdasan Emosional terhadap Prestasi Belajar} Matematika Siswa.

Temuan penelitian menunjukkan bahwa Prestasi Belajar Matematika Siswa yang diukur oleh Kecerdasan Emosional, menunjukkan adanya korelasi yang cukup signifikan dan memiliki pengaruh yang kuat (lebih besar dari 0,05) terhadap Prestasi Belajar Matematika Siswa. Besarnya pengaruh langsung Kecerdasan Emosional terhadap Prestasi Belajar Matematika adalah $K D=\mathbf{p}_{13}{ }^{2} \times \mathbf{1 0 0 \%}=\mathbf{0 , 4 1 9 \times 0 , 4 1 9} \times 100$ $\boldsymbol{\%}=\mathbf{1 7 , 5 5 \%}$, dan sisanya $\mathbf{8 2 , 4 5 \%}$ dipengaruhi oleh faktor lainnya diluar Kecerdasan Emosional.

Berdasarkan hasil perhitungan diatas, maka hasil penelitian sesuai dengan pengajuan hipotesis penelitian yang menyatakan bahwa terdapat pengaruh langsung Kecerdasan Emosional terhadap Prestasi Belajar Matematika Siswa. Namun demikian pengaruhnya tidak terlalu besar hanya $\mathbf{1 7 , 5 5} \%$, angka ini lebih rendah dari pengaruh tidak langsung Kecerdasan Emosional terhadap Prestasi Belajar Matematika melalui Minat Belajar Matematika yang memiliki pengaruh sebesar 25\%.

Walaupun pengaruh langsung Kecerdasan Emosional terhadap Prestasi Belajar Matematika hanya 17,55\%, tetapi terdapat korelasi yang positif. Goleman (2002:512) Kecerdasan Emosional adalah kemampuan seseorang mengatur kehidupan emosinya dengan intelegensi (to manage our emosional life with intelligence); menjaga keselarasan emosi dan pengungkapannya (appropriateness of emosion and its expression) melalui keterampilan kesadaran diri, pengendalian diri, motivasi diri, empati dan keterampilan social. Goleman berpendapat bahwa Kecerdasan Emosional adalah kemampuan lebih yang dimiliki seseorang dalam memotivasi diri, ketahanan dalam menghadapi kegagalan, mengendalikan emosi dan menunda kepuasan, serta mengatur keadaan jiwa.

Dari pendapat Goleman diatas dapat disimpulkan bahwa Kecerdasan Emosional mempunyai pengaruh langsung terhadap Penguasaan Konsep Matematika Siswa. Siswa yang cerdas secara emosi memiliki kemampuan memotivasi diri dengan baik, bisa mengendalikan emosinya sehingga mampu memusatkan perhatiannya terhadap pelajaran matematika. Atensi yang tinggi sangat dibutuhkan siswa untuk memahami materi matematika yang komplek dan umumnya berkenaan dengan ide-ide abstrak yang tersusun secara sistematis serta membutuhkan kegiatan mental yang tinggi.

Oleh karena itu untuk meningkatkan dan mempertahankan Prestasi Belajar Matematika Siswa, salah satunya adalah dengan meningkatkan Kecerdasan Emosional siswa. Untuk meningkatkan Kecerdasan Emosional (EQ) juga harus didukung oleh kecerdasan Intelektual (IQ). (Goleman, 2002:512) Dalam proses belajar siswa, kedua intelegensi ini sangat diperlukan. IQ tidak akan berfungsi dengan baik tanpa partisipasi penghayatan emosional terhadap mata pelajaran yang disampaikan. Namun kedua intelegensi ini saling melengkapi. Keseimbangan IQ dan EQ merupakan kunci keberhasilan siswa dalam memahami materi pelajaran matematika.

Hasil penelitian membuktikan adanya pengaruh Kecerdasan Emosional terhadap Penguasaan Konsep Matematika Siswa. (Cepi dan Risma, 2008:25), seseorang dengan keterampilan emosional berkembang baik, berarti kemungkinan 
besar ia akan berhasil dalam kehidupannya dan memiliki motivasi untuk berprestasi. Sedangkan individu yang tidak dapat menahan kendali atas kehidupan emosionalnya akan mengalami pertarungan batin yang merusak kemampuannya untuk memusatkan perhatian pada tugas-tugasnya.Berdasarkan temuan penelitian ini terlihat bahwa Prestasi Belajar Matematika Siswa dipengaruhi oleh Kecerdasan Emosional.

\section{Pengaruh langsung Minat Belajar terhadap Prestasi Belajar Matematika Siswa.}

Temuan penelitian menunjukkan terdapat pengaruh yang signifikan antara Minat Belajar Matematika dengan Prestasi Belajar Matematika siswa, hal ini ditunjukkan oleh angka koefisien korelasi sebesar $\mathbf{0 , 6 5 5}$ dan sig < 0,05 pada analisis korelasi.Terdapat pengaruh langsung yang signifikan Minat Belajar Matematika terhadap Penguasaan Konsep Matematika Siswa. Hal ini ditunjukkan oleh angka koefisien jalur sebesar 0,387 (lebih besar dari 0,05). Besar pengaruh Minat Belajar Matematika terhadap Prestasi Belajar Matematika adalah $\mathbf{K D}=\mathbf{P}_{\mathbf{2 3}} \mathbf{2}^{\mathbf{x} 100 \%}=$ $\mathbf{0 , 3 8 7 x 0 , 3 8 7 x} 100 \%=14,97 \%$, sedangkan sisanya sebesar 85,03\% dipengaruhi oleh faktor lainnya diluar Minat Belajar Matematika.

Berdasarkan temuan ini menunjukkan bahwa variabel Minat Belajar Matematika memiliki pengaruh yang signifikan terhadap Prestasi Belajar Matematika. Sardiman, (2000:56), anak yang mencapai suatu prestasi, sebenarnya merupakan hasil kecerdasan dan minat.(Sutikno, 2007:2) menyatakankan, minat yang besar akan mendorong motivasi siswa itu sendiri. Jadi seorang anak tidak mungkin sukses dalam segala aktivitas tanpa adanya minat.

Minat sangat erat hubungannya dengan belajar, belajar tanpa minat akan terasa membosankan. Siswa yang berminat terhadap kegiatan belajar akan berusaha lebih keras dibandingkan siswa yang kurang berminat. Minat yang tinggi terhadap matematika memungkinkan siswa memberikan perhatian yang tinggi terhadap mata pelajaran matematika, sehingga memungkinkan untuk memiliki prestasi yang tinggi dalam matematika.

Hal ini menunjukkan bahwa patut diduga akan lebih efektif meningkatkan Prestasi Belajar Matematika siswa, jika dilakukan dengan meningkatkan minat belajar matematika siswa terlebih dahulu. Sehingga siswa merasa lebih tertarik dan suka tanpa paksaan pada mata pelajaran matematika. Dengan adanya minat maka siswa akan lebih mencurahkan perhatiannya secara penuh dan menganggap kesulitan sebagai tantangan. Siswa lebih bergairah mengerjakan soal-soal matematika yang akan berimbas pada Prestasi Belajar Matematika dengan baik. Berdasarkan temuan penelitian tersebut terlihat bahwa Minat Belajar Matematika dapat mempengaruhi Prestasi Belajar Matematika Siswa.

\section{Pengaruh langsung Kecerdasan Emosional terhadap Minat Belajar Matematika} Siswa.

Temuan penelitian menunjukkan adanya korelasi yang signifikan antara Kecerdasan Emosional terhadap Minat Belajar Matematika Siswa, hal ini ditunjukkan oleh angka koefisien korelasi sebesar 0,640 dan sig $<0,05$ pada analisis korelasi.Terdapat pengaruh langsung dan signifikan Kecerdasan Emosional terhadap Minat Belajar Matematika Siswa. Hal ini ditunjukkan oleh angka koefisien jalur sebesar 0,640 (lebih besar dari 0,05). Besarnya pengaruh Kecerdasan Emosional terhadap Minat Belajar Matematika Siswa adalah $\mathbf{K D}=\mathbf{P}_{\mathbf{1 2}}{ }^{2} \mathbf{x} \quad \mathbf{1 0 0 \%}=$ 0,640x0,640x100\% $=40,96 \%$, sedangkan sisanya sebesar 59,04\% dipengaruhi oleh faktor lainnya diluar Kecerdasan Emosional. 
Hasil penelitian membuktikan bahwa adanya pengaruh yang signifikan Kecerdasan Emosional terhadap Minat Belajar Matematika Siswa. Temuan penelitian ini menunjukkan bahwa variabel Minat Belajar Matematika berpengaruh lebih signifikan dibandingkan variabel kecerdasan Emosional terhadap Prestasi Belajar Matematika. Belly (2006:4), Minat adalah keinginan yang didorong oleh sesuatu setelah melihat, mengamati dan membandingkan serta mempertimbangkan dengan kebutuhan yang diinginkannya. Dari pendapat tadi jelas tergambar bahwa Kecerdasan Emosional memiliki peranan dalam menumbuhkan minat belajar matematika siswa. Pendapat ini didukung oleh Goleman (2005:512) Kecerdasan emosional adalah kemampuan yang dimiliki seseorang dalam memotivasi diri, ketahanan dalam menghadapi kegagalan, mengendalikan emosi dan menunda kepuasan serta mengatur keadaan jiwa. Dari kedua pendapat itu dapat disimpulkan bahwa kecerdasan emosional akan membantu siswa untuk meningkatkan minat belajar matematikanya, terutama kemampuan memotivasi diri dan mengendalikan emosinya. Pendapat ini didukung oleh pendapat lain dari Sutikno (2007:2), adanya intelengensi yang memadai membuat siswa makin percaya diri serta mampu mengelola emosi dengan baik. (Sumardiono, 2007:1690) menyatakan bahwa rasa percaya diri dalam diri siswa dapat mendorong tumbuhnya minat belajar. Siswa yang meiliki keterampilan emosional umumnya lebih kompeten secara akademis, lebih mampu menyusun gagasan secara nalar, lebih bergairah dalam belajar dibandingkan dengan siswa yang tidak memiliki keterampilan emosional yang baik. Berdasarkan temuan penelitian tersebut terlihat bahwa Kecerdasan Emosional dapat mempengaruhi Minat Belajar Matematika Siswa.

\section{Pengaruh tidak langsung Kecerdasan Emosional terhadap Prestasi Belajar Matematika Siswa melalui Minat Belajar Matematika.}

Temuan penelitian menunjukkan bahwa terdapat pengaruh yang signifikan Kecerdasan Emosional terhadap Prestasi Belajar Matematika Siswa melalui Minat Belajar Matematika.Hal ini dapat dilihat dari besarnya pengaruh tidak langsung yaitu $\mathbf{P}_{12} \times P_{23} \times 100 \%=0,640 \times 0,387 \times 100 \%=24,76 \%$, sedangkan sisanya sebesar $\mathbf{7 5 , 2 4 \%}$ dipengaruhi oleh faktor lainnya.

Berdasarkan temuan penelitian ini menunjukkan bahwa peningkatan Prestasi Belajar Matematika dapat dilakukan dengan peningkatan Kecerdasan Emosional melalui peningkatan Minat Belajar Matematika siswa. Menurut Sardiman (2000:56), anak yang mencapai suatu prestasi, sebenarnya merupakan hasil kecerdasan dan minat. Seorang siswa yang memiliki kecerdasan emosional yang berkembang baik akan lebih terampil dalam menenangkan diri, lebih baik dalam memusatkan perhatian dan memotivasi diri untuk meningkatkan minat belajar, serta lebih cakap dalam memahami orang lain.

Dari hasil pengumpulan data melalui angket yang disebarkan pada siswa diketahui bahwa minat belajar matematika siswa baik. Begitu juga dengan kecerdasan emosional siswa termasuk kategori baik, hal ini dapat dilihat dari hasil penyebaran tes. Minat yang baik dan kecerdasan emosional yang baik berpengaruh pada prestasi belajar matematika siswa.

Hal ini menunjukkan bahwa jelas diduga akan lebih efektif meningkatkan prestasi belajar matematika siswa jika dilakukan dengan meningkatkan kecerdasan emosional siswa terlebih dahulu, agar bisa meningkatkan minat belajar matematikanya. Siswa akan lebih cerdas dalam bertindak, lebih terampil mengendalikan emosinya,bisa berpikir secara rasional, serta memiliki gairah yang tinggi pada mata pelajaran matematika. Dengan demikian siswa akan lebih tertarik 
pada matematika, memiliki motivasi berprestasi dan memberi hasil yang lebih baik terhadap prestasi belajar matematika.

\section{PENUTUP}

\section{Simpulan}

Berdasarkan hasil hasil penelitian dan analisis data serta pengujian hipotesis, maka dapat disimpulkan bahwa:

1. Terdapat pengaruh langsung yang signifikan Kecerdasan Emosional terhadap Prestasi Belajar Matematika Siswa. Hal ini dibuktikan dengan hasil pengujian hipotesis melalui analisis jalur $\mathbf{t}_{\mathbf{h}}>\mathbf{t}_{\mathbf{t}}(\mathbf{4 , 5 9 4}>\mathbf{1 , 9 8 0})$ yang berarti ada pengaruh langsung yang signifikan.

2. Terdapat pengaruh langsung yang signifikan Minat Belajar Matematika terhadap Prestasi Belajar Matematika. Hal ini dibuktikan dengan hasil pengujian hipotesis melalui analisis jalur $\mathbf{t}_{\mathbf{h}}>\mathbf{t}_{\mathbf{t}}(\mathbf{4 , 2 3 6}>\mathbf{1 , 9 8 0})$ yang berarti ada pengaruh langsung yang signifikan.

3. Terdapat pengaruh langsung yang signifikan Kecerdasan Emosional terhadap Minat Belajar Matematika Siswa. Hal ini dibuktikan dengan hasil pengujian hipotesis melalui analisis jalur $\mathbf{t}_{\mathbf{h}}>\mathbf{t}_{\mathbf{t}}(\mathbf{8 , 1 5 6}>\mathbf{1 , 9 8 0})$ yang berarti ada pengaruh langsung yang signifikan.

4. Terdapat pengaruh tidak langsung yang signifikan Kecerdasan Emosional terhadap Prestasi Belajar Matematika melalui Minat Belajar Matematika Siswa. Hal ini dibuktikan dengan hasil pengujian hipotesis melalui analisis jalur $\mathbf{t}_{\mathbf{h}}>\mathbf{t}_{\mathbf{t}}(\mathbf{2 , 9 7}>$ 1,980) yang berarti ada pengaruh tidak langsung yang signifikan.

\section{Saran}

Berdasarkan simpulan penelitian, maka dapat dirumuskan beberapa saran dengan penekanan sebagai berikut:

1. Meningkatkan kecerdasan emosional siswa dilakukan dengan cara: kenali watak dan karakter masing-masing anak, guru harus mampu menunjukkan rasa kasih sayang dan mampu mengendalikan emosi negatif (amarah),guru sebaiknya mampu dan sabar melayani setiap keinginan siswa terhadap materi pelajaran,guru harus bisa menciptakan suasana pembelajaran yang menyenangkan dan nyaman dengan memberikan rasa aman dan bebas secara psikologis, memberikan kesempatan pada siswa untuk berkreativitas dan berpartisipasi aktif.

2. Meningkatkan minat belajar siswa dilakukan dengan cara: tidak monoton dalam penyampaian materi, gunakan atau manfaatkan sarana pembelajaran semaksimal mungkin, ciptakan suasana belajar yang kondusif dan tidak tegang meskipun pada materi yang sulit, sesekali disertai dengan candaan untuk mencairkan suasana, selalu bangkitkan motivasi siswa agar tumbuh minat dan ketertarikan pada mata pelajaran matematika, libatkan siswa secara aktif dalam pembelajaran, biarkan mereka brekreativitas dan berikan contoh-contoh serta aplikasinya dalam kehidupan seharihari, jika perlu berikan reward atau hadiah-hadiah kecil yang merangsang minat siswa.

\section{DAFTAR PUSTAKA}

Agustian, Ary Ginanjar. 2005. Rahasia Sukses Membangun Kecerdasan Emosi dan Spritual. Jakarta: Arga.

Alwi, Idrus. 2012. Statistika untuk Penelitian Pendidikan. Jakarta: Saraz Publishing. Anni, C.T. dkk. 2004. Psikologi Belajar. Universitas Negeri Semarang Press. Arikunto, Suharsimi. 2010. Prosedur Penelitian. Jakarta: Rineka Cipta. 
Cooper, Robert K. dan Anyam Sawaf. 1998. Executive EQ: KecerdasanEmosional Dalam Kepemimpinan dan Organisasi. Jakarta: PT Gramedia Pustaka Utama.

Darajat, Zakiah dkk. 2007. Metode Khusus Pengajaran Agama Islam. Jakarta: Bumi Aksara.

Gagne, G. D. 1985. The Cognitive Psychology Of School Learning.

Goleman, Daniel. 2000. Emotional Intelligence (Kecerdasan Emosional). Jakarta: Gramedia Pustaka Umum.

Goleman, Daniel. 2002.Working With Emotional Intelligence (terjemahan).Jakarta: PT. Gramedia

Gottman, Jhon. 2001. Kiat-Kiat Membesarkan Anak yang Memiliki Kecerdasan Emosional (terjemahan). Jakarta: PT Gramedia Pustaka Utama.

Surya, Hendra. 2007. Percaya Diri Itu Penting. Jakarta: Elex Media Komputindo.

Houle.1961. The Inquiring Mind. University of Madison Press Madison.

Hudoyo, H.1998. Mengajar Belajar Matematika. Jakarta: Dirjen DIKTI Depdikbud.

Imron, Ali. 1996. Belajar dan Pembelajaran. Jakarta: Dunia Pustaka.

Jhon, Gray.2005. Mars dan Venus on a date. Jakarta: Gramedia.

Kurniawan.2006. Siap Juara Olimpiade Matematika SMP. Jakarta: Erlangga.

Mardapi dan Ghofur, A.2007. Pedoman Umum Pengembangan Penilaian, Kurikulum

Berbasis Kompetensi SMA. Jakarta: Direktorak Pendidikan Menengah Umum.

Syah, Muhibbin. 2010. Psikologi Pendidikan dengan Pendekatan Baru. Bandung: Rosdakarya.

Purwanto, Ngalim. 1990. Psikologi Pendidikan. Bandung: Remaja Rosdakarya.

Riduwan. 2007. Belajar Mudah Penelitian Untuk Guru- karyawan dan Peneliti pemula. Bandung Alfabeta.

Rohiat. 2008. Kecerdasan Emosional Kepemimpinan Kepala Sekolah. Bandung: Refika Aditama.

Sahabuddin. 2003. Mengajar dan Belajar "Dua Aspek dan Suatu Proses Pendidikan". Makasar: Universitas Negeri Makassar Press.

Ruseffendi. 2010. Pengajaran Matematika untuk Meningkatkan CBSA. Bandung: Tarsito.

Shapiro, E. Lawrence. 1997. Mengajarkan Emosional Intelligence Kepada Anak. Diterjemahkan oleh Alex Tri Kantjono. Jakarta: Gramedia Pustaka.

Slameto.2003. Belajar dan factor-faktor yang mempengaruhinya. Jakarta: Rineka Cipta

Soedjadi, R. 2000. Kiat pendidikan Matematika di Indonesia - Konstalasi Keadaan Masa Kini Menuju Harapan bangsa. Jakarta: Rineka Cipta

Sudijono, Anas. 2007. Pengantar Evaluasi Pendidikan. Jakarta: Raja Grafindo

Sudjana, Nana. 2008. Penilaian Hasil Proses Belajar Mengajar. Bandung: PT. Remaja Rosdakarya.

Sudjana, Nana. 1987. Dasar - Dasar Proses Belajar Mengajar. Bandung: Sinar Baru Algensindo.

Sumardiono.2007. Home Schooling a Leap for Better Learning"Lompatan Cara Belajar"Jakarta:PT Elex Media Komputindo.

Solso, L, Robert. 2008. Psikologi Kognitif. Jakarta: Erlangga.

Sunarto, H. dan B. Agung Hartono. 2006. Perkembangan Peserta Didik. Jakarta: PT. Rineka Cipta.

Triatna, Cepi dan Risma Kharisma. 2008. EQ Power Panduan meningkatkan Kecerdasan Emosional. Bandung: Citra Praya.

Supardi U.S. 2013. Aplikasi Statistika dalam Penelitian. Jakarta: Change Publisher.

W. S. Winkel. 1996. Psikologi Pengajaran. Jakarta: Grasindo. 